\title{
Introduction, Establishment, and Invasion of Digitonthophagus gazella (Fabricius, 1787) (Coleoptera: Scarabaeinae) in the Savannas of Venezuela and Colombia
}

\author{
Jorge Ari Noriega ${ }^{1,2 *}$, Oona Delgado 3 , Joffre Isnar Blanco ${ }^{4}$ Jorge Gámez $^{5}$, José Clavijo³ \\ ${ }^{1}$ Laboratorio de Zoología y Ecología Acuática-LAZOEA, Universidad de Los Andes, Bogotá, Colombia \\ ${ }^{2}$ Department of Biogeography and Global Change, National Museum of Natural Science (CSIC), Madrid, Spain \\ ${ }^{3}$ Museo del Instituto de Zoología Agrícola Francisco Fernández Yépez-MIZA, Facultad de Agronomía, Universidad Central de \\ Venezuela, Maracay, Venezuela \\ ${ }^{4}$ Laboratorio de Entomología, Universidad Nacional Experimental del Táchira, San Cristóbal, Venezuela \\ ${ }^{5}$ Fundación Entomológica Andina, Mérida, Venezuela \\ Email: ¡jnorieg@hotmail.com
}

How to cite this paper: Noriega, J.A., Delgado, O., Blanco, J.I., Gámez, J. and Clavijo, J. (2017) Introduction, Establishment, and Invasion of Digitonthophagus gazella (Fabricius, 1787) (Coleoptera: Scarabaeinae) in the Savannas of Venezuela and Colombia. Natural Resources, 8, 370381.

https://doi.org/10.4236/nr.2017.85023

Received: March 25, 2017

Accepted: May 21, 2017

Published: May 26, 2017

Copyright $\odot 2017$ by authors and Scientific Research Publishing Inc. This work is licensed under the Creative Commons Attribution International License (CC BY 4.0).

http://creativecommons.org/licenses/bv/4.0/

\begin{abstract}
The invasion process involves overcoming certain barriers with negative effects on the biodiversity and ecosystem function. This is the case of the African dung beetle Digitonthophagus gazella, which was introduced in the United States and other countries in Central and South America to help in dung removal activity. The distribution of $D$. gazella has been documented in the Americas, but in Venezuela there is little information. Trying to understand the process of invasion of the Colombian-Venezuelan savannas and measure their potential impact, the information stored in collections and literature was collected. Five new state records were reported for Venezuela, as well as four scenarios of the process of introduction and establishment of this species in the region. Although the amount of records has increased, the number of individuals sampled is still incipient. The possible areas of invasion and the potential negative effects that the presence of this species exerts in these regions are also discussed. In addition, potential areas of invasion and negative effects of this species are discussed. Results emphasize the importance of generating models of the invasive process in order to design programs that monitor the effects incurred by the presence of $D$. gazella on native species and propose control and mitigation mechanisms.
\end{abstract}

\section{Keywords}

Anthropic Introduction, Biodiversity, Dung Beetles, Invasive Species, Scarabaeidae 


\section{Introduction}

The invasive process of a foreign species is made up of successive steps that consist in its overcoming environmental, geographical, and demographical barriers in a way that it is able to disperse extensively. Thus, invasive species with a stable population can generate threats to local species [1] [2] [3]. In ecosystems, invasive species have been under study for over two decades now [4]. It is known that some invasive species can alter a community's species structure (abundance, diversity, composition, and biomass) having negative effects on the ecosystem's biodiversity [5] and functionality [6].

Since the anthropic introduction of the African dung beetle Digitonthophagus gazella (Fabricius, 1787) [7] [8] in 1970 in Texas-USA [9] [10] to assist in the removal of cattle feces, its dispersion has been documented in Mexico [11] [12] [13], Guatemala [14], Nicaragua [15], the Greater Antilles: Cuba (F. Vaz-deMello pers. comm.), Jamaica, La Española (Dominican Republic), Puerto Rico, the Lesser Antilles: St. Croix, Anguila, St. Kitts, Monserrat, Guadalupe, Marie-Galante [16], Martinique [17] and Granada [14].

Within South America, D. gazella has been recorded due to both dispersion and unofficial introduction events in Colombia [18]-[25], Bolivia [26], Paraguay [27], Peru [28], and Argentina [29]; and only due to unofficial introduction events in Brazil [30] [31] [32], continental Chile, and Easter Island [33].

Although there are detailed records of the invasion process in North America, particularly for Mexico [11] [12] [13] [14] [34] [35] [36] [37] [38] the available information is still little in South America, especially for Venezuela. In order to fill in this information gap and to understand the possible effect on local biodiversity during the species' process of introduction, establishment, and invasion in the savannas of Venezuela and Colombia, the following study was performed.

\section{Materials and Methods}

The information from public and private collections was gathered, field expeditions to specific locations were implemented, and all bibliographic material was validated in order to construct a detailed map of the current distribution of $D$. gazella in the savannas of Venezuela and Colombia. With all these information we try to understand the biogeographic patterns of the introduction and establishment of the species'. The zoological collections examined in Venezuela were: Entomological Collection of the Andean Entomology Foundation (CEFUNEA), Tachira Joffre Blanco Entomology Collection (METJB), and Museo del Instituto de Zoología Agrícola "Dr. Francisco Fernández Yépez" (MIZA). Distribution maps were generated using ArcView GIS version 3.2.

\section{Results and Discussion}

\section{New records}

Five new state reports have been established for Venezuela from the informa- 
tion gathered in the zoological collections, constituting the first official record for this species in the country and expanding its known distribution range (Figure 1). For Colombian records we put together all the available information of the distribution pattern of this species [18]-[25].

Examined material: Venezuela. Apure: 1 우, $1 \hat{f}$, Municipio Rómulo Gallegos, Hato La Yeguera, Caño Guaritico, Jun 2006, A. Orellana, leg., METJB.

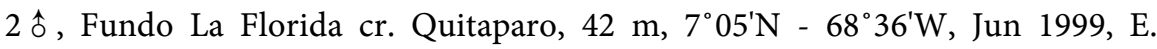
Osuna \& A. Chacón, leg., MIZA. Bolívar: 4 우, 1 오, Guri, 200 m, Jun-Jul 1998, L.J. Joly, J.L. García \& Y. Zavala, leg., light trap, MIZA. Cojedes: 6 우, $6 \hat{o}$, Hacienda El Palmar, Sep 2005, MIZA. Gúarico: 12 우, $22 \hat{0}$, Nicolasito, $08^{\circ} 08^{\prime} 20^{\prime \prime N}-66^{\circ} 24^{\prime} 32^{\prime \prime W}$, Jan 2000, J. Clavijo, M. Gaiani, R. Briceño, Q. Arias \& A. Chacón, leg., MIZA. Táchira: 1 우, 1 소, Municipio García de Hevia, La fría, Feb 2007, J. Blanco, leg., METJB. 2 우, 2 ô, Municipio Jáuregui, La Quinta, road la grita, Mar 2008, 1400 m, J. Blanco, leg., METJB.

\section{Records of the dispersal process of $D$. gazella in Venezuela}

The following reports constitute the records of the processes of introduction, establishment, and invasion of $D$. gazella in Venezuela.

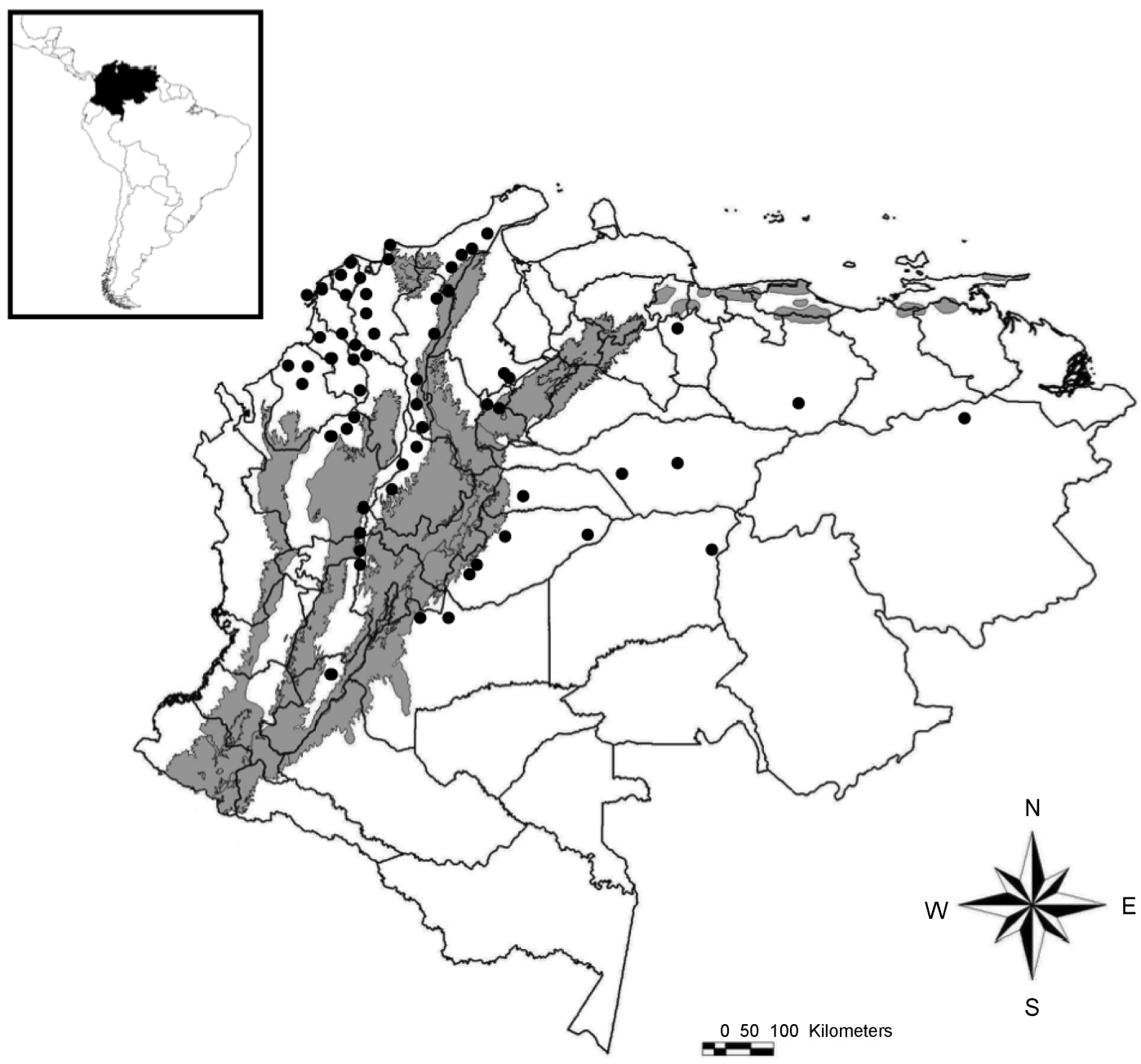

Figure 1. Distribution map of the actual records of Digitonthophagus gazella in Colombia and Venezuela. 
1) Maracaibo Lake-Zulia (1990's-1996)

In Venezuela at the start of the 90's, there is information to suppose that a group of Englishmen unofficially liberated D. gazella individuals in cattle ranches to increase the recycling rate of dung (J. Blanco unpub. data). This liberation coincides in time with the liberations in Brazil and Chile. The first sampling of D. gazella in Venezuelan territory was carried out in 1996 within the State of Zulia, municipality of Colon, in the Santa Ana Ranch on introduced pastures [39]. At this locality, eight different species were surveyed and D. gazella (initially identified as Onthophagus sp. 1) was the most abundant (38.41\%; n = 2112 ind.) showing an established population and corroborating that the species was introduced before the completion of the survey [39]. In this locality and surrounding areas (El Recreo, Bancada de Limones, Colon-Zulia) D. gazella has been collected throughout the year in cattle dung and pitfall traps with human excrements, appearing only in grasslands away from the banana fields (secondary vegetation in regeneration) and not as abundantly as in the initial records (J. Gámez unpub. data).

2) Bolívar, Apure, and Guárico-Venezuela midland (1998-2000)

The following records in Venezuela correspond to the States of Bolívar in 1998 ( $\mathrm{n}=5$ ind.), Apure in 1999 ( $\mathrm{n}=2$ ind.), and Guárico in 2000 ( $\mathrm{n}=34$ ind.). Although these records indicate low population densities, this is because the surveys carried out were not of systematic character nor were intended to calculate the species' population densities in the area. The survey carried out in the State of Bolivar is of special interest because this region is located in the south portion of the Orinoco River, a potential geographical barrier for the dispersal of the species that may be related to the growing livestock industries.

3) Cojedes and Táchira (2005-2008)

Between the years 2005 and 2008 new records were obtained for D. gazella in Venezuela. New individuals were captured in the State of Cojedes in 2005 ( $\mathrm{n}=$ 12 ind.) and in the State of Tachira in 2007 ( $n=2$ ind.) and in 2008 ( $n=4$ ind.), however still obtaining low population densities. In addition, new localities were registered for the State of Apure.

Increase in the records and establishment of $D$. gazella

A general trend of increase is observed in the records and presence of D. gazella for the new localities. In this study the presence of D. gazella is reported for the first time in five States of Venezuela: Apure, Bolivar, Cojedes, Guárico and Táchira. The analysis of these records demonstrates an increase in the distribution range and establishment of this species in Venezuelan territory. The number of individuals detected in these new records is still low when compared to other dominant native species such as Canthidium euchalceum Balthasar, Canthon acutus Harold, Onthophagus landolti Harold and Onthophagus marginicollis Harold. It's demonstrating that $D$. gazella is still in a stage of establishment in various localities and hasn't yet become an invasive species at a regional scale. However, the reversal of this relationship is possible within a short timespan according to the records in the State of Zulia where show that D. gazella is a competitive species, with high dispersal, and ability to exploit the local resources of 
domestic and native animals ([14] [36] [38] [40], C. Flechtmann pers. comm., J.A. Noriega unpub. data). This suggests that $D$. gazella has the potential to be considered an invasive species.

Hypothetical scenarios for the processes of arrival and dispersion of $D$. gazella

Using the new records for Venezuela in this paper and all the available records for Colombia, we propose four hypothetical scenarios for the arrival and dispersal of D. gazella in the Venezuelan and Colombian savannas. The first two (A and $\mathrm{B})$ consider that the species arrived through natural dispersion processes, and the last two (C and D) consider their arrival to be a consequence of anthropic liberation processes (Figure 2):

A) In this first scenario $D$. gazella initially comes from the colonization through Central America, despite the fact that the nearest country where the species has been recorded is in Nicaragua [15] since there are no available records for either Costa Rica or Panama (B. Kohlmann and A. Solis pers. comm.).

(a)

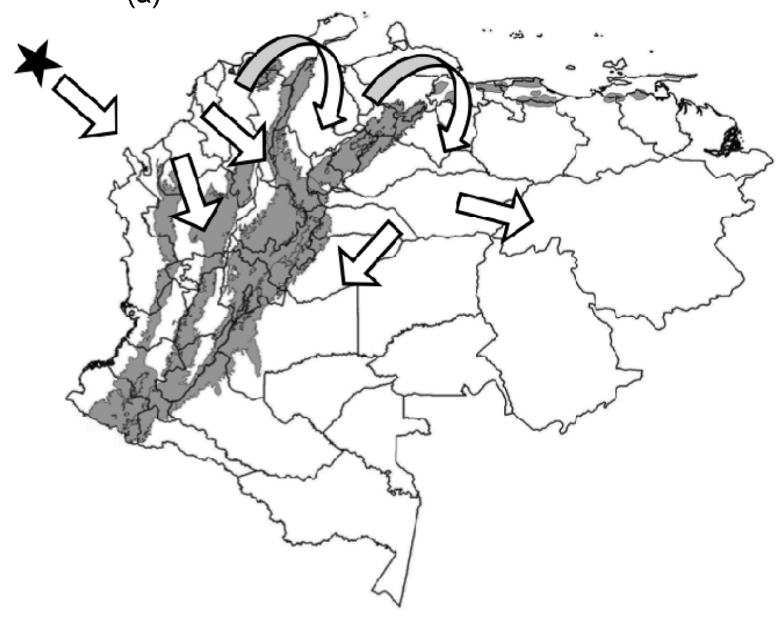

(c)

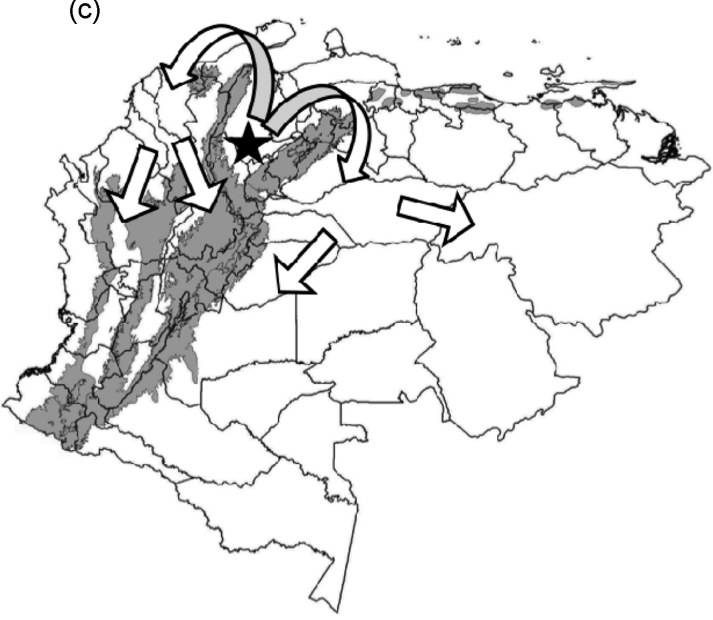

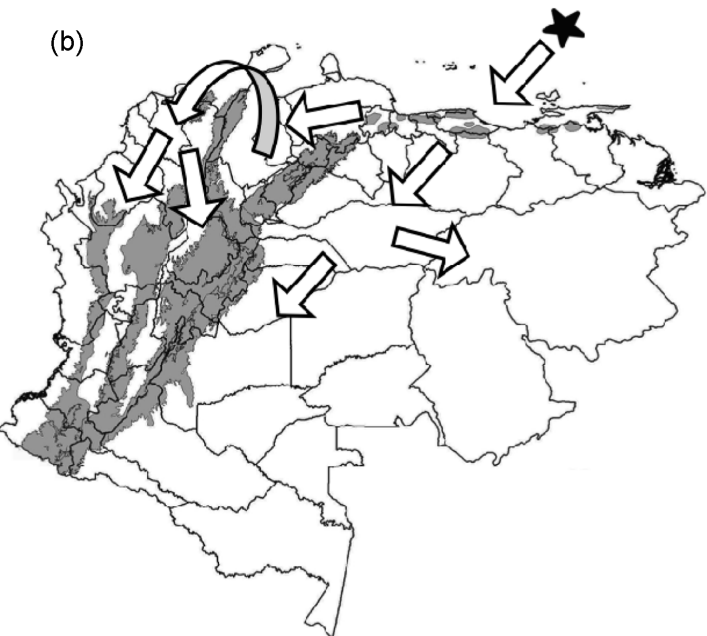

(d)

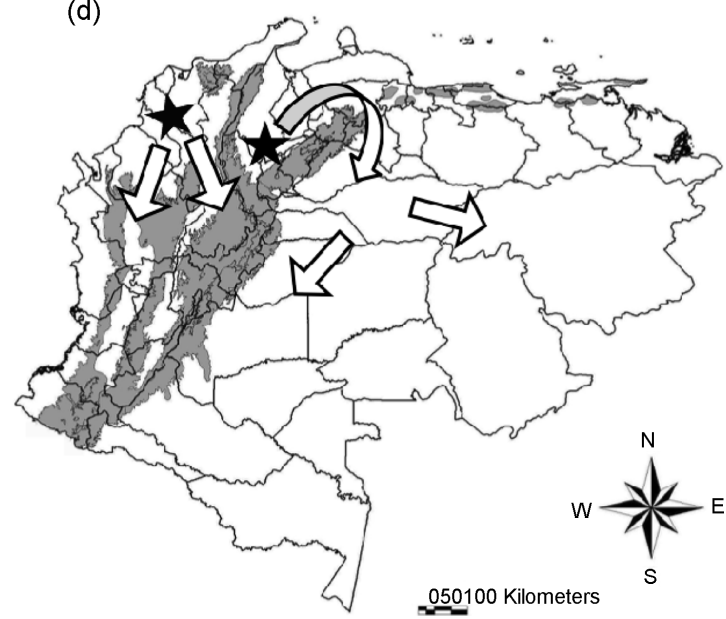

Figure 2. Hypothetical scenarios ((a), (b), (c) and (d)) of the arrival or introduction, and dispersal of Digitonthophagus gazella in Colombia and Venezuela according to the records. $\star=$ point of origin for the arrival or introduction of $D$. gazella. 
The species would have initially entered through the Caribbean region of Colombia, constituting two dispersion fronts: the first front towards the inter-Andean valleys of the Magdalena and Cauca Rivers in Colombia, and the second front towards the vicinities of Lake Maracaibo in Venezuela. In this scenario, the Andes mountain range would have constituted a strong geographical barrier [41]. Subsequently, the species would have proceeded along two additional new fronts: the first towards the States of Bolivar, Apure, and Guarico in the Venezuelan midland, and the second towards the Venezuelan and Colombian savannas.

B) In this second scenario D. gazella would arrive through the Antilles, origin that is strongly supported by records both in the Greater Antilles ([14], F. Vaz-de-Mello pers. comm.) as in the Lesser Antilles [14] [16] [17]. The nearest record to the continent is the one in the Island of Granada [14], which is situated at $135 \mathrm{~km}$ from the coast. The species would have entered first through Venezuela, presenting two dispersion fronts: the first front goes through the Caribbean region towards Lake Maracaibo, and the second front towards the midland States of Bolivar, Apure, and Guarico. Also, in this scenario, the Andes mountain range would have constituted a strong geographical barrier [41]. Subsequently, from Lake Maracaibo it would have entered Colombia towards the Caribbean region and in a second phase preceded towards the inter-Andean valleys of the Magdalena and Cauca Rivers. In parallel, the species would have advanced towards the Venezuelan and Colombian savannas.

C) In this third scenario the arrival of D. gazella would have been by means of an unofficial anthropic introduction in Venezuelan territory (J. Blanco unpub. data). It would establish two dispersion fronts from the location of its introduction: the first front going towards the Caribbean region of Colombia, and the second front towards the Venezuelan midland States of Bolivar, Apure, and Guárico. Similarly, in this scenario, the Andes mountain range would have constituted a strong geographical barrier [41]. Subsequently, the species would have proceeded along two additional new fronts: the first towards the Venezuelan and Colombian savannas, and the second towards the inter-Andean valleys of the Magdalena and Cauca Rivers.

D) In this fourth scenario the arrival of $D$. gazella would have been by means of two unofficial anthropic introductions occurring in a parallel way in Venezuela and Colombia, although for Colombia there is no record of an anthropic introduction of the species before the one carried out in the state of Antioquia by the Wyeth Laboratories Inc. in 2007 [42]. Subsequently, the species would have proceeded along two fronts: the first front towards the inter-Andean valleys of the Magdalena and Cauca Rivers in Colombia, and the second front towards the Venezuelan midland States of Bolivar, Apure, and Guárico. In a final phase the species would have dispersed towards the Venezuelan and Colombian savannas.

Potential invasion areas of $D$. gazella

Digitonthophagus gazella possess a broad distribution range within the Colombian and Venezuelan territories, occupying mainly open habitats, savannas, 
pastures, and altered landscapes, especially those for livestock use that are situated under $1500 \mathrm{~m}$. Although the species hasn't been registered in any regions of high endemicity yet, the existence of a steady flow of livestock could facilitate their entry to more susceptible areas [22] [23] [24]. Similarly, the invasion of Venezuelan and Colombian savannas can come to be very fast and could have negative effects on local species populations given that no natural barriers exist for their dispersion and invasion.

In Venezuela, it is probable that the species has already colonized the complete vicinities of Lake Maracaibo and entered the States of Anzoátegui, Barinas and Portuguesa, as well as occupied the introduced pastures in the Southern regions of the Lake corresponding to the States of Mérida and Trujillo. Similarly, it is probable that it will disperse throughout the plains region, which covers $200,000 \mathrm{~km}^{2}$ of Venezuelan territory [43]. The main geographic barriers in Venezuela, other than the Andes [41], are the rainforests in the States of Amazonas and Bolivar, and the xerophytic shrubs, marshes, and mangroves of the Caribbean region.

The limited records in Venezuelan territory may be the result of a lack of surveys in more relevant regions or because of low population densities. Additionally, it should be noted that until recently in Venezuela the species had been inaccurately identified as Onthophagus sp. [39]. If the dispersal rate of 200 $\mathrm{km}$ /year recorded in other localities is maintained [14], this species could end up occupying most part of the Venezuelan and Colombian territory (lowlands, inter-Andean valleys, savannas, and pasture corridors at intermediate altitudes) in less than three years.

On top of all this, the added effect of anthropic activity could potentiate its dispersal capacities. This is especially true when considering liberations by the hands of institutions such as the EMBRAPA in Brazil [30] [31], who have promoted the introduction and rearing of the species in certain Latin-American countries without conducting previous population studies and with no control whatsoever. Another negligent case is that of the state of Antioquia in Colombia, where the presence of $D$. gazella can be attributed to the implementation of a seed stock of the species in 2008 by Wyeth Laboratories Inc. [42] in the municipality of Barbosa that was authorized by the Ministry of Environment, Housing, and Territorial Development without carrying out appropriate studies of its potential environmental impact. In this sense, there are few studies that have tried to quantify the functional role of this species concerning excrement recycling and fly-control within Neotropical regions, because of which the available information is not only incomplete, but also insufficient to decree mass introduction of the species.

\section{Potential negative effects of $D$. gazella invasion}

Given that D. gazella presents a high dispersal capacity [13] [35], high individual mobility [44], high reproductive rate [45] [46], and opportunistic behavioral strategies in relation to trophic resources [47], it is a species with an elevated potential to cause negative effects upon native species [48]. In areas where 
D. gazella's habitat requirements overlap with those of species possessing narrow niches; these may become strongly compromised, resulting in local extinctions especially in the case of low-density populations.

In one of the localities in Texas where D. gazella was originally introduced, tracking of its population numbers has registered an increase in the species' abundance to values constituting up to $30 \%$ of the beetle species composition in the ecosystem ( $\mathrm{n}=11,709$ of 40,079 ind.; 21 spp.) [49]. In other regions, the negative effects of $D$. gazella upon the population structure of dominant native species, such as Ateuchus histeroides (Weber) and Copris minutus (Drury) in Georgia-USA, has been observed in the drastic reduction of their population numbers in response to competition with D. gazella for trophic resources [40].

In Colombia (J.A. Noriega unpub. data) and Brazil (C. Flechtmann pers. comm.) similar negative effects have been observed in native ecosystems' species composition, resulting in sharp declines in their population numbers and presumed local extinctions of native species that have not been recorded again since D. gazella's establishment. On the other hand, in other localities these effects are not as apparent, making it seem as though their native species assemblages are less susceptible to invasive species negative effects [50] [51]. However, this may be due to the fact that $D$. gazella is still in the initial moments of its establishment in these areas. In addition, Anduaga [37] says that despite the virtues attributed to $D$. gazella, this species does not fulfill its role as a mediator efficiently since it recycles excrement at a small scale due to its small size. This results in a small amount of relocated excrement and at a shallow depth, not being sufficient to control fly and parasite activity.

It's imperative to generate biogeographical models using the available information on the natural history and barriers of this species to clearly understand the process of introduction, establishment, and invasion in areas with endemic species [52]. Also, it is important to implement programs that monitor D. gazella populations on native species and recommend control and mitigation mechanisms of its negative effects.

\section{Acknowledgements}

To the Zoology and Aquatic Ecology Laboratory (LAZOEA). To Andrés Orellana for collecting some of the samples in the State of Apure. To the directors and curators of the entomological collections: the Entomological Collection of the Andean Entomology Foundation (CEFUNEA), the Tachira Joffre Blanco Entomology Collection (METJB), and the Museo del Instituto de Zoología Agrícola "Dr. Francisco Fernández Yépez" (MIZA). To Ricardo Botero-Trujillo, José Ignacio Barrera, Ingrid Quintero, Cesil Solís, and Carolina Vizcaíno for their valuable comments and insights to the various versions of the manuscript. To Luis J. Joly, Carlos A. Flechtmann, Fernando Vaz-de-Mello, Bert Kohlmann and Angel Solís for the information provided and valuable contributions to the study. To Javier Santos and David Morris for their valuable help in the correction and revision of the English version of the manuscript. 


\section{References}

[1] Davis, M.A. and Thompson, K. (2000) Eight Ways to Be an Invader: A Proposed Nomenclature Scheme for Invasion Ecology. Bulletin of the Ecological Society of America, 81, 226-230.

[2] Mack, R.N., Simberloff, D., Lonsdale, W.M., Evans, H., Clout, M. and Bazzaz, F. (2000) Biotic Invasions: Causes, Epidemiology, Global Consequences and Control. Ecological Applications, 10, 689-710. https://doi.org/10.1890/1051-0761(2000)010[0689:bicegc]2.0.co;2

[3] Richardson, D.E., Pyšek, P., Rejmanek, M., Barbour, M.G., Panetta, F.D. and West, C.J. (2000) Naturalization and Invasion of Alien Plants: Concepts and Definitions. Diversity and Distributions, 6, 92-107. https://doi.org/10.1046/j.1472-4642.2000.00083.x

[4] Simberloff, D. (1996) Impacts of Introduced Species in the United States. Consequences. Nat. Implic. Environ. Change, 2, 13-22.

[5] Sakai, A.K., Allendorf, F.W., Holt, J.S., Lodge, D.M., Molofsky, J., With, K.A., Baughman, S., Cabin, R.J., Cohen, J.E., Ellstrand, N.C., McCauley, D.E., O’Neil, P., Parker, I.M., Thompson, J.N. and Weller, S.G. (2001) The Population Biology of Invasive Species. Annual Review of Ecology and Systematics, 32, 305-332. https://doi.org/10.1146/annurev.ecolsys.32.081501.114037

[6] Money, H.A. and Hobbs, R.J. (2000) Invasive Species in a Changing World. Island, Washington DC, $457 \mathrm{p}$.

[7] Génier, F. and Davis, A.L.V. (2017) Digitonthophagus gazella Auctorum: An Unfortunate Case of Mistaken Identity for a Widely Introduced Species (Coleoptera: Scarbaeidae: Scarbaeinae: Onthophagini). Zootaxa, 4221, 497-500.

https://doi.org/10.11646/zootaxa.4221.4.8

[8] Génier, F. and Moretto, P. (2017) Digitonthophagus Blathasar, 1959: Taxonomy, Systematics, and Morphological Phylogeny of the Genus Revealing an African Species Complex (Coleoptera: Scarabaeidae: Scarabaeinae). Zootaxa, 4248, 1-110. https://doi.org/10.11646/zootaxa.4248.1.1

[9] Blume, R.R. and Aga, A. (1978) Onthophagus gazella: Progress of Experimental Releases in South Texas. Folia Entomológica Mexicana, 39-40, 190-191.

[10] Fincher, G.T., Stewart, T.B. and Hunter III, J.S. (1983) The 1981 Distribution of Onthophagus gazella Fabricius from Releases in Texas and Onthophagus taurus Schreber from an Unknown Release in Florida (Coleoptera: Scarabaeidae). The Coleopterists Bulletin, 37, 159-163.

[11] Rivera-Cervantes, L.E. and García-R., E. (1991) New Locality Records for Onthophagus gazella Fabricius (Coleoptera: Scarabaeidae) in Jalisco, México. The Coleopterists Bulletin, 45, 370.

[12] Lobo, J.M. and Montes de Oca, E. (1997) Spatial Microdistribution of Two Introduced Dung Beetles Species Digitonthophagus gazella (F.) and Euoniticellus intermedius (Reiche) (Coleoptera: Scarabaeidae) in an Arid Region of Northern Mexico (Durango, Mexico). Acta Zoológica Mexicana (n.s.), 71, 17-32.

[13] Montes de Oca, E. and Halffter, G. (1998) Invasion of Mexico by Two Dung Beetles Previously Introduced into the United States. Studies on Neotropical Fauna and Environment, 33, 37-45. https://doi.org/10.1076/snfe.33.1.37.2174

[14] Kohlmann, B. (1994) A Preliminary Study of the Invasion and Dispersal of Digitontophagus gazella (Fabricius, 1787) in México (Coleoptera: Scarabaeidae: Scarabaeinae). Acta Zoológica Mexicana (n.s.), 61, 35-42.

[15] Maes, J.M., Ratcliffe, B.C. and Jameson, M.L. (1997) Fauna entomológica de la 
Reserva Natural Bosawas, Nicaragua. XI. Escarabajos (Coleoptera: Scarabaeidae) nuevos para la fauna de Nicaragua. Revista Nicaragüense de Entomológica, 39, 4145.

[16] Ivie, M.A. and Philips, T.K. (2008) Three New Species of Canthonella Chapin from Hispaniola, with New Records and Nomenclatural Changes for West Indian Dung Beetles (Coleoptera: Scarabaeidae: Scarabaeinae). Zootaxa, 1701, 1-14.

[17] Huchet, J.B. (1992) Un scarabée nouveau pour les Petites Antilles: Digitonthophagus gazella (Fabricius) [Col. Scarabaeidae, Coprinae, Onthophagini]. L'Entomologiste, 48, 297-303.

[18] Noriega, J.A. (2002) FIRST report of the Presence of the Genus Digitonthophagus (Coleoptera: Scarabaeidae) in Colombia. Caldasia, 24, 213-215.

[19] Noriega, J.A., Solis, C., Quintero, I., Perez, L.G., Garcia, H.G. and Ospino, D.A. (2006) Registro Continental de Digitonthophagus gazella (Coleoptera: Scarabaeidae) en Colombia. Caldasia, 28, 379-381.

[20] Rivera, C. and Wolff, M. (2007) Digitonthophagus gazella (Coleoptera: Scarabaeidae): Distribución en América y dos nuevos registros para Colombia. Revista Colombiana de Entomología, 33, 190-192.

[21] Navarro, I.L., Roman, A.K., Gomez, F.H. and Perez, H.A. (2009) Primer registro de Digitonthophagus gazella (Fabricius, 1787) para el departamento de Sucre, Colombia. Revista Colombiana de Ciencia Animal Recia, 1, 60-64.

[22] Noriega, J.A., Moreno, J. and Otavo, S. (2011) Quince años del arribo del escarabajo coprófago Digitonthophagus gazella (Fabricius, 1787) (Coleoptera: Scarabaeidae) a Colombia: Proceso de invasión y posibles efectos de su establecimiento. Biota Colombiana, 12, 35-44.

[23] Noriega, J.A., Moreno, J., Otavo, S. and Castaño, E. (2012) New Departamental Records for Digitonthophagus gazella (Coleoptera: Scarabaeidae) in Colombia. Acta Biológica Colombiana, 17, 201-204.

[24] Noriega, J.A., Solis, C., Garcia, H., Murillo-Ramos, L., Renjifo, J.M. and Olarte, J.E. (2013) Sinopsis de los escarabajos coprofagos (Coleoptera: Scarabaeinae) del Caribe Colombiano. Caldasia, 35, 465-477.

[25] Noriega, J.A. (2016) First Report of Latrodectus geometricus Koch (Araneae: Theridiidae) as a Predator of Digitonthophagus gazella (Fabricius) (Coleoptera: Scarabaeidae). The Coleopterist Bulletin, 70, 407-408. https://doi.org/10.1649/0010-065X-70.2.407

[26] Vidaurre, T., Noriega, J.A. and Ledezma, M.J. (2008) First Report on the Distribution of Digitonthophagus gazella (Fabricius, 1787) (Coleoptera: Scarabaeidae) in Bolivia. Acta Zoologica Mexicana (n.s.), 24, 217-220.

[27] Ruiz, M.A. (2000) Levantamento populacional de besouros coprofagos (Coleoptera Scarabaeidae) no Estado de Amambay, Republica do Paraguay. Tese de Mestrado em Entomologia, Paraguay, 80 p.

[28] Noriega, J.A., Horgan, F.G., Larsen, T.H. and Valencia, G. (2010) Records of an Invasive Dung Beetle Species, Digitonthophagus gazella (Fabricius, 1787) (Coleoptera: Scarabaeidae), in Peru. Acta Zoológica Mexicana (n.s.), 26, 451-456.

[29] Álvarez, M.C., Damborsky, M.P., Bar, M.E. and Ocampo, F.C. (2009) Registros y distribución de la especie afroasiática Digitonthophagus gazella (Coleoptera: Scarabaeidae: Scarabaeinae) en Argentina. Revista de la Sociedad Entomológica Argentina, 68, 373-376.

[30] Miranda, C.H.B., do Nacimiento, Y.A. and Bianchin, I. (1990) Desenvolvimiento de um programa integrado de controle dos nematodeos e a mosca-dos-chifres na 
região dos cerrados. Fase 3. Potencial de Onthophagus gazella no enterrio de fezes bovinas. EMBRAPA. Centro Nacional de Pesquisa de Gado de Corte, 42, 1-5.

[31] Nascimento, Y.A., Blanchin, I. and Honer, M.R. (1990) Instruções para a criação do besouro Onthophagus gazella em laboratório. Empresa Brasilera de Pesquisa Agropecuaria (EMBRAPA), Comunicado Técnico No. 33.

[32] Bianchin, I., Alves, R.G.O. and Koller, W. (1998) Efeito de Carrapaciticidas/ Insecticidas "Pour-On" sobre adultos do besouro coprofago africano Onthophagus gazella Fabr. (Coleoptera: Scarabaeidae). Anais da Sociedade Entomológica do Brasil, 27, 275-279. https://doi.org/10.1590/S0301-80591998000200014

[33] Ripa, R.S., Rojas, P.S. and Velasco, G. (1995) Releases of Biological Control Agents of Insects Pests on Eastern Island (Pacific Ocean). Entomophaga, 40, 427-440. https://doi.org/10.1007/BF02373730

[34] Zunino, M. and Halffter, G. (1988) Análisis taxonómico, ecológico y biogeográfico de un grupo americano de Onthophagus (Coleoptera, Scarabaeidae). Monografie di Museo Regionale di Scienze Naturali di Torino, 9, 1-211.

[35] Barbero, E. and López-Guerrero, Y. (1992) Some Considerations on the Dispersal Power of Digitonthophagus gazella (Fabricius 1787) in the New World (Coleoptera, Scarabaeidae, Scarabaeinae). Tropical Zoology, 5, 115-120. https://doi.org/10.1080/03946975.1992.10539184

[36] Lobo, J.M. (1996) Diversity, Biogeographical Considerations and Spatial Structure of a Recently Invaded Dung Beetle (Coleoptera: Scarabaeoidea) Community in the Chihuahuan Desert. Global Ecology and Biogeography Letters, 5, 342-352. https://doi.org/10.2307/2997589

[37] Anduaga, S. (2004) Impact of the Activity of Dung Beetles (Coleoptera: Scarabaeidae: Scarabaeinae) Inhabiting Pasture land in Durango, Mexico. Environmental Entomology, 33, 1306-1312. https://doi.org/10.1603/0046-225X-33.5.1306

[38] Delgado, L. and Márquez, J. (2006) Estado del conocimiento y conservación de los coleópteros Scarabaeoidea (Insecta) del estado de Hidalgo, México. Acta Zoológica Mexicana (n.s.), 22, 57-108.

[39] Gámez, J., Mora, E. and de Ascencao, A. (1997) Coleópteros copronecrófilos (Scarabaeidae) en un sistema agropastoril en el sur del Lago de Maracaibo. Resúmen XV Congreso Venezolano de Entomología, Trujillo, Venezuela, 51.

[40] Young, O.P. (2007) Relationships between an Introduced and Two Native Dung Beetle Species (Coleoptera: Scarabaeidae) in Georgia. Southeastern Naturalist, 6, 491-504. https://doi.org/10.1656/1528-7092(2007)6[491:RBAIAT]2.0.CO;2

[41] Gámez, J. (2010) Escarabajos necrófagos (Coleoptera: Scarabaeidae: Scarabaeinae: Phanaeini y Coleoptera: Silphidae: Nicrophorinae y Silphinae) de la cordillera de los Andes, depresión de Maracaibo y Llanos de Venezuela. Kempffiana, 6, 15-19.

[42] Ministerio de Ambiente, Vivienda y Desarrollo Territorial (MinAmb) (2008) Resolución número (0880) 29 de Mayo de 2008. Bogotá, Colombia, 23 p.

[43] Silva, J.F. (2003) Sabanas. En: Aguilera, M., Azocar, A. and González-Jiménez, E., Eds., Biodiversidad en Venezuela. Tomo II, Fundación Polar y FONACIT, Caracas, Venezuela, 678-695.

[44] Seymour, J. (1980) Dung Beetles Get a Little Help from Their Friends. Ecos, 26, 20-25.

[45] Rougon, C. and Rougon, D. (1980) Contribuition à la biologie des coléopteres coprophages en region sahélienne. Ėtude du développement d'Onthophagus gazella (Coleoptera: Scarabaeidae). Reevue d Ecologie et de Biologie du Sol, 17, 379-392.

[46] Lee, J.M. and Peng, Y.S. (1982) Influence of Manure Availability and Nesting Den- 
sity on the Progeny Size of Onthophagus gazella. Environmental Entomology, 11, 38-41. https://doi.org/10.1093/ee/11.1.38

[47] Cambefort, Y. (1984) Étude écologique des coléoptères Scarabaeidae de Côte d'Ivoire. Travaux des Chercheurs de la Station de Lamto (Côte d' Ivoire), 3, 1-320.

[48] Zunino, M. and Barbero, E. (1993) Escarabajos, ganado, pastizales: Algunas consideraciones deontológicas. Folia Entomológica Mexicana, 87, 95-101.

[49] Fincher, G.T., Blume, R.R., Hunter III, J.S. and Beerwinkle, K.R. (1986) Seasonal Distribution and Diel Flight Activity of Dung-Feeding Scarabs in Open and Wooded Pasture in East-Central Texas. Southwestern Entomologist, 10, 1-35.

[50] Horgan, F.G. (2007) Dung Beetles in Pasture Landscapes of Central America: Proliferation of Synanthropogenic Species and Decline of Forest Specialists. Biodiversity Conservation, 16, 2149-2165. https://doi.org/10.1007/s10531-006-9145-3

[51] Matavelli, R.A. and Louzada, J.N.C. (2008) Invasão de áreas de savana intraamazônicas por Digitonthophagus gazella (Fabricius, 1787) (Insecta: Coleoptera: Scarabaeidae). Acta Amazónica, 38, 153-158. https://doi.org/10.1590/S0044-59672008000100017

[52] Lawton, J.H. and Brown, K.C. (1986) The Population and Community Ecology of Invading Insects. Philosophical Transactions of the Royal Society of London Series B, 314, 607-616. https://doi.org/10.1098/rstb.1986.0076

\section{Submit or recommend next manuscript to SCIRP and we will provide best service for you:}

Accepting pre-submission inquiries through Email, Facebook, LinkedIn, Twitter, etc. A wide selection of journals (inclusive of 9 subjects, more than 200 journals) Providing 24-hour high-quality service User-friendly online submission system Fair and swift peer-review system Efficient typesetting and proofreading procedure Display of the result of downloads and visits, as well as the number of cited articles Maximum dissemination of your research work

Submit your manuscript at: http://papersubmission.scirp.org/

Or contact nr@scirp.org 